\title{
Peningkatan Kepekaan Biosensor Urea Berasaskan Resonans Plasmon Permukaan dan Tatasusunan Kretschmann dengan Struktur Hibrid Grafin- $\mathrm{MoS}_{2}$ \\ (Sensitivity Enhancement of Urea Biosensor based on Surface Plasmon Resonance and Kretschmann Configuration with Graphene- $\mathrm{MoS}_{2}$ Hybrid Structure)
}

\author{
Nur AKMAR Jamil, P. Susthitha MenON*, GAN SiEW Mei, Burhanuddin YeOP MaJlis
}

\begin{abstract}
ABSTRAK
Artikel ini menganalisis biosensor resonans plasmon permukaan (SPR) dengan lapisan grafin yang meningkatkan kecekapan biosensor urea kerana penerapannya yang tinggi. Tatasusunan Kretschmann merupakan teknik yang paling berkesan digunakan untuk pengujaan plasmon. Dalam kajian ini, kami menganalisis kesan ekalapisan MoS, dengan lapisan grafin yang didepositkan pada bahan plasmon, iaitu logam emas (Au), di dalam tatasusunan ini. Simulasi untuk menganalisis tatasusunan ini adalah berdasarkan kepada kaedah perbezaan terhingga domain masa (FDTD). Prestasi biosensor SPR dapat dipantau dengan menganalisis kepekaan dan lebar penuh pada separuh maksimum (FWHM) spektrum SPR. Pengukuran diperhatikan pada panjang gelombang $670 \mathrm{~nm}$ dan $785 \mathrm{~nm}$ untuk pengesanan urea. Indeks molar dan indeks biasan berbeza (RI) daripada 1.335 sehingga 1.342 untuk lapisan penderiaan. Keputusan menunjukkan peratus peningkatan kepekaan biosensor Au/MoS/grafin berbanding biosensor Au konvensional adalah $98 \%$ dan $202 \%$ masingmasing pada panjang gelombang $670 \mathrm{~nm}$ dan $785 \mathrm{~nm}$. Ini menunjukkan bahawa cadangan biosensor SPR yang novel ini adalah lebih sensitif untuk pengesanan urea.
\end{abstract}

Kata kunci: Biosensor urea; FWHM; resonans plasmon permukaan; simulasi FDTD; tatasusunan Kretschmann

ABSTRACT

The present paper analyses a surface plasmon resonance (SPR) biosensor based on graphene that leads to improvement on the efficiency of an urea biosensor due to high adsorption. Kretschmann configuration is well known as the most effectively used technique for plasmon excitation. In this work, we investigated the effect of $\mathrm{MoS}_{2}$ with a fine layer of graphene deposited on a plasmonic material, gold ( $\mathrm{Au})$, into the configuration. Simulation is based on finite-difference time domain (FDTD) method for analysis. The performance of SPR biosensor can be monitored by analyzing the sensitivity and full width-at-half-maximum (FWHM) of the SPR spectrum. The measurements are observed at 670 and $785 \mathrm{~nm}$ for urea detection. The molarity and refractive index is varied from 1.335 to 1.342 for the sensing layer. The results showed that the percentage increase in sensitivity for the proposed biosensor Au/MoS/graphene over conventional biosensor Au is $98 \%$ and $202 \%$ at 670 and $785 \mathrm{~nm}$, respectively, which indicates that the proposed novel SPR biosensor is better suited for urea detection.

Keywords: FDTD simulation; FWHM; Kretschmann configuration; surface plasmon resonance; urea biosensor

\section{PENGENALAN}

Plasmon adalah mod resonans yang melibatkan interaksi antara elektron bebas dan cahaya. Ionosfera dan logam, kedua-duanya adalah contoh plasmon, iaitu media yang mempunyai elektron mudah alih yang membentuk gas elektron bebas. Fenomena resonans plasmon permukaan (SPR) berlaku disebabkan oleh perambatan gelombang elektromagnet di sepanjang permukaan lapisan logam nipis. Secara praktikal, sedikit perubahan indeks biasan pada lapisan sampel dielektrik akan menyebabkan perubahan pada polariton plasmon permukaan (SPP). Perubahan ini diukur secara optikal melalui teknik pantulan keseluruhan dikecilkan (ATR). Tujuan utama penggunaan teknik gandingan ini adalah untuk memadankan gelombang vektor cahaya tuju dengan gelombang vektor SPP (Mukhtar et al. 2013; Said et al. 2015a).
Rajah 1 menunjukkan tatasusunan Kretschmann yang menggunakan teknik gandingan prisma. Tatasusunan ini terdiri daripada prisma, kaca bersalut lapisan emas dan sampel luar. Cahaya magnet melintang (TM) akan menyebabkan gelombang SPP teruja pada prisma bersalut dengan bahan-bahan plasmon (Mukhtar et al. 2014; Tarumaraja et al. 2016). Pengujaan SPP terhasil daripada ayunan menegak yang dialami oleh elektron pada antara muka dielektrik-logam. Cahaya tuju polarisasi-p dipantulkan pada filem nipis logam bersalut emas dengan indeks biasan (RI) tinggi dan melalui sampel luar dengan indeks biasan rendah. Pada sudut yang tertentu, SPR terhasil menyebabkan keamatan cahaya pantulan berkurang. Aplikasi yang sering menggunakan fenomena SPR ini adalah seperti dalam bidang penderiaan, iaitu untuk mengesan kehadiran racun perosak, urea, protein dan enzim. 
Urea merupakan produk akhir hasil daripada penguraian protein dan ia merupakan bahan buangan dalam badan manusia. Terdapat pelbagai kaedah untuk mengesan tahap kandungan urea dalam badan, salah satunya adalah melalui analisis klinikal. Walau bagaimanapun, kaedah penganalisan dalam makmal ini agak rumit dan mengambil masa yang lama. Oleh itu, dengan penggunaan kaedah tanpa label, seperti biosensor resonans plasmon permukaan (SPR), adalah merupakan ciptaan baru menggunakan teknik moden yang tidak invasif dan lebih tepat untuk pengesanan awal sesuatu gejala akibat kehadiran urea di tahap tinggi dalam tubuh manusia. Biosensor menggunakan SPR ini telah digunakan secara meluas sebagai kaedah waktu nyata yang dapat menganalisis interaksi antara biomolekul.

Pemilihan logam untuk digunakan pada struktur biosensor adalah amat penting. Emas dan perak merupakan logam yang biasa digunakan untuk aplikasi komersial kerana kestabilan ciri-ciri optik dan kimia pada bahan tersebut (Kravets et al. 2014). Dengan ini, cahaya pada panjang gelombang yang sesuai mampu bergema untuk menghasilkan resonans plasmon permukaan. Selain daripada logam yang dinyatakan, logam lain seperti tembaga, aluminium dan palladium juga boleh digunakan pada permukaan prisma kaca tersebut. Walaupun emas kerap digunakan dalam struktur sensor, namun emas mempunyai kelemahan kerana ia merupakan bahan penjerap yang lemah terhadap biomolekul sehingga mengurangkan kepekaan sensor tersebut. Untuk mengatasi isu kepekaan sensor, pelbagai bahan alternatif telah digunakan dalam tatasusunan Kretschmann. Bahan grafin merupakan salah satu pilihan utama para penyelidik pada masa kini kerana memiliki ciri-ciri optik, mekanikal dan elektrik yang luar biasa (Iqbal et al. 2015; Said et al. 2017). Bahan grafin adalah sangat unggul kerana memiliki penyerapan optik yang baik hasil daripada struktur kekisi sarang lebah dua dimensi (Chia et al. 2013; Lee et al. 2016). Ini menjadikan grafin lebih kuat dan stabil kerana interaksi susunan $\pi-\pi$ antara atom (Said et al. 2016). Selain itu, grafin juga sebagai unsur pengenalan biomolekul dapat meningkatkan kepekaan biosensor (Verma et al. 2011). Terdapat bahan dua dimensi lain yang diterokai baru-baru ini, iaitu molibdenum disulfida $\left(\mathrm{MoS}_{2}\right)$ yang tergolong dalam kelas semikonduktor logam peralihan dichalcogenide (TMDC). Bahan $\mathrm{MoS}_{2}$ telah dikenali dengan kecekapan penyerapan optik yang lebih tinggi berbanding grafin (Maurya et al. 2016).

Oleh itu, gabungan $\mathrm{MoS}_{2}$ dan grafin dipercayai dapat meningkatkan prestasi sensor kerana kehilangan tenaga elektron pada $\mathrm{MoS}_{2}$ akan memindahkan tenaga cahaya sepenuhnya ke substrat penderiaan. Ini dapat ditunjukkan dalam kajian, dengan kepekaan sensor meningkat sebanyak $12.82 \%$ dengan gabungan lapisan grafin dan $\mathrm{MoS}_{2}$ dan lapisan komposit $\mathrm{TiO}_{2}-\mathrm{SiO}_{2}$ berbanding dengan sensor SPR konvensional (Maurya et al. 2015). Untuk prestasi biosensor yang lebih baik, tahap kepekaan yang maksimum dan pantulan yang minimum adalah dikehendaki. Dalam kertas ini, kami mengubah suai struktur biosensor SPR konvensional dengan menggunakan lapisan grafin dan $\mathrm{MoS}_{2}$ (Jamil et al. 2017a).

\section{MODEL BERANGKA}

Simulasi model biosensor berasaskan SPR dibangunkan menggunakan perisian komersil FDTD solver yang diperoleh daripada Lumerical, Inc. (Said et al. 2015b). Penyelesaian optik berprestasi tinggi untuk merakam interaksi antara cahaya dengan geometri logam berskala panjang memerlukan penetapan ultra-halus dan jejaring selaras yang sesuai untuk simulasi struktur plasmon. Satu lagi analisis yang memberi kelebihan dalam aplikasi pemodelan optikal adalah sapuan parameter. Pemodelan optik ini boleh dilakukan dalam simulasi tunggal yang menyediakan pelbagai sudut sumber tuju dalam panjang gelombang pantulan dan penghantaran.

Dalam kajian ini, tatasusunan prisma Kretschmann yang dikenali umum digunakan sebagai peralatan asas untuk mengesan perubahan pada SPR seperti yang

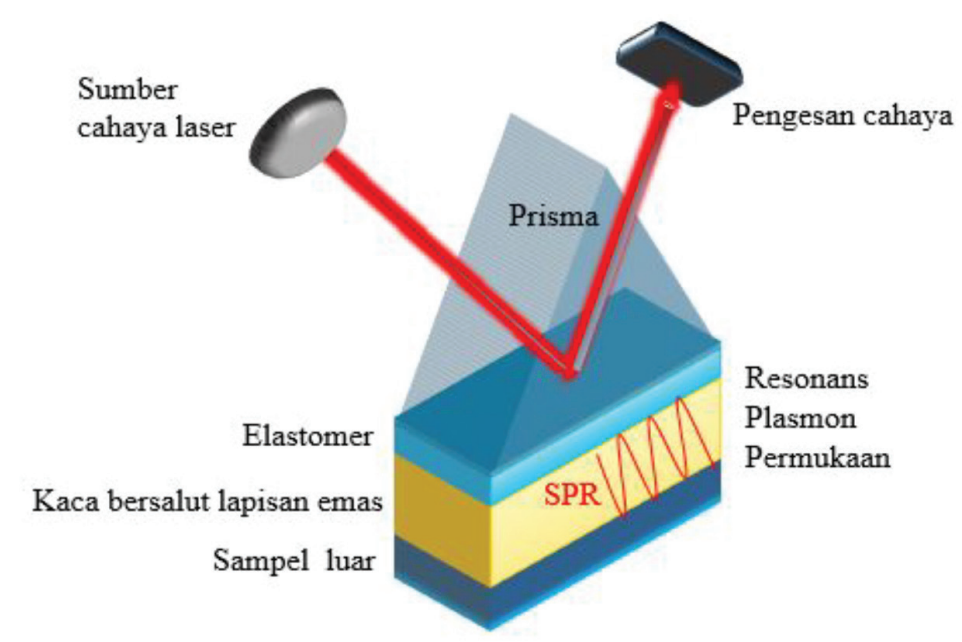

RAJAH 1. Gambarajah biosensor SPR berdasarkan tatasusunan Kretschmann 
ditunjukkan dalam Rajah 2. Tatasusunan biosensor SPR yang dicadangkan terdiri daripada enam komponen, iaitu prisma kaca, kromium $(\mathrm{Cr})$, lapisan emas $(\mathrm{Au})$, ekalapisan $\mathrm{MoS}_{2}$, lapisan grafin dan media penderiaan. Panjang gelombang optik yang digunakan pada satu per seribu juta meter (nanometer) adalah 670 dan $785 \mathrm{~nm}$. Indeks biasan komplek pada kaca, filem $\mathrm{Cr}$ dan Au diperoleh daripada data ukuran eksperimen (Jussila et al. 2016). Seterusnya, lapisan keempat adalah ekalapisan $\mathrm{MoS}_{2}$ dengan nilai RI $5.3413+1.2781 i$ dan 4.8150 masing-masing pada panjang gelombang $670 \mathrm{~nm}$ dan $785 \mathrm{~nm}$ (Rubio-Bollinger et al. 2015). Ketebalan $\mathrm{MoS}_{2}$ diberikan sebagai $M \times 0.65 \mathrm{~nm}$ dengan $M$ ialah bilangan lapisan $\mathrm{MoS}_{2}$. Lapisan kelima adalah lapisan grafin dan RI adalah $3.1+0.5 i$. Ketebalan laipsan grafin diberikan sebagai $L \times 0.37 \mathrm{~nm}$ dengan $L$ ialah bilangan lapisan grafin (Aksimsek \& Sun 2016). Lapisan keenam adalah lapisan penginderaan. Dalam kertas ini, kepekatan urea diambil sebagai lapisan penginderaan dengan julat RI adalah dari 1.335 hingga 1.342 (Ahmad 2010). Julat sudut tuju pula ditetapkan dari 40 hingga 80 darjah.

Pengukuran eksperimental akan dilakukan kelak di IMEN, UKM menggunakan alat Bionavis SPR Navi-200 yang dilengkapi dengan dua panjang gelombang sahaja iaitu $670 \mathrm{~nm}$ dan $785 \mathrm{~nm}$. Beberapa kajian lepas menggunakan panjang gelombang pengujaan $633 \mathrm{~nm}$ tetapi dalam kajian ini panjang gelombang pengujaan yang lebih panjang digunakan untuk menghasilkan puncak resonans yang lebih sempit. Ini adalah untuk mendapatkan prestasi SPR yang terbaik, ia penting untuk mencapai lebar lengkap pada separa maksimum (FWHM) yang agak rendah kerana ia menjanjikan penentuan lebih tepat mengenai sudut modulasi dengan nilai FWHM bergantung kepada dua faktor iaitu panjang gelombang pengujaan dan bilangan lapisan $\mathrm{MoS}_{2}$ (Ouyang et al. 2016).

Pengujaan gelombang SPP adalah berdasarkan kepada pantulan dalaman penuh dengan nilai keamatan pantulan minimumnya diperoleh. Pada sudut yang tertentu, junaman dalam lengkung pantulan SPR diambil sebagai sudut resonans $\left(\theta_{\text {res }}\right)$ bagi kehadiran kepekatan urea (Jamil et al. 2017b). Keamatan pantulan minimum $\left(R_{\min }\right)$ cahaya berlaku apabila keamatan maksimum cahaya digunakan untuk menjana SPR. Oleh itu, apabila kepekatan urea meningkat, perubahan pada sudut resonans $\left(\Delta \theta_{\text {res }}\right)$ berlaku. Prestasi biosensor SPR boleh diperoleh berdasarkan tahap kepekaan dimana lebih tinggi nilainya akan menghasilkan biosensor yang lebih baik dan peka terhadap perubahan indeks biasan. Kepekaan $(S)$ ditakrifkan sebagai nisbah perubahan sudut resonans kepada perubahan indeks biasan (RIU). FWHM adalah perbezaan antara dua nilai sudut tuju dimana keamatan pantulan sama dengan separa nilai maksimum. Lebih kecil nilai FWHM adalah lebih baik tahap pengesanan biosensor kerana puncak resonans yang lebih mendalam dan sempit (Said et al. 2015b).

\section{KEPUTUSAN DAN PERBINCANGAN}

Dalam kertas ini, simulasi adalah mimik eksperimen sebenar Jussila et al. (2016) dengan keputusannya menunjukkan persetujuan dengan data eksperimen yang diperoleh. Titik pantulan dalaman penuh dapat dilihat pada $41^{\circ}$, manakala dengan sudut yang meningkat, jumlah cahaya menurun dengan ketara disebabkan oleh anjakan puncak resonans plasmon permukaan dari $42^{\circ}$ ke $43^{\circ}$ (sudut pantulan).

Rajah 3 menunjukkan lengkung pantulan biosensor SPR untuk ketiga-tiga struktur pada gelombang 670 dan 785 $\mathrm{nm}$ dalam media udara dielektrik $(\mathrm{n}=1)$. Struktur sensor I hanya mempunyai lapisan Au dan diplotkan sebagai garis nyata hitam dengan bentuk segiempat pejal hitam (ם). Struktur sensor II terdiri daripada $\mathrm{Au} / \mathrm{MoS}_{2}$ diplotkan sebagai garis pejal merah dengan bentuk berlian pejal merah ( ). Akhir sekali, struktur sensor III mempunyai lapisan $\mathrm{Au} / \mathrm{MoS}_{2} /$ Grafin diplotkan sebagai garis pejal biru dengan bentuk segitiga pejal biru $(\mathbf{\Delta})$.

Jelas kelihatan bahawa sudut resonans pada Struktur III ( $\mathrm{Au} / \mathrm{MoS}_{2} /$ grafin) telah berganjak sedikit pada keduadua panjang gelombang berbanding dengan biosensor

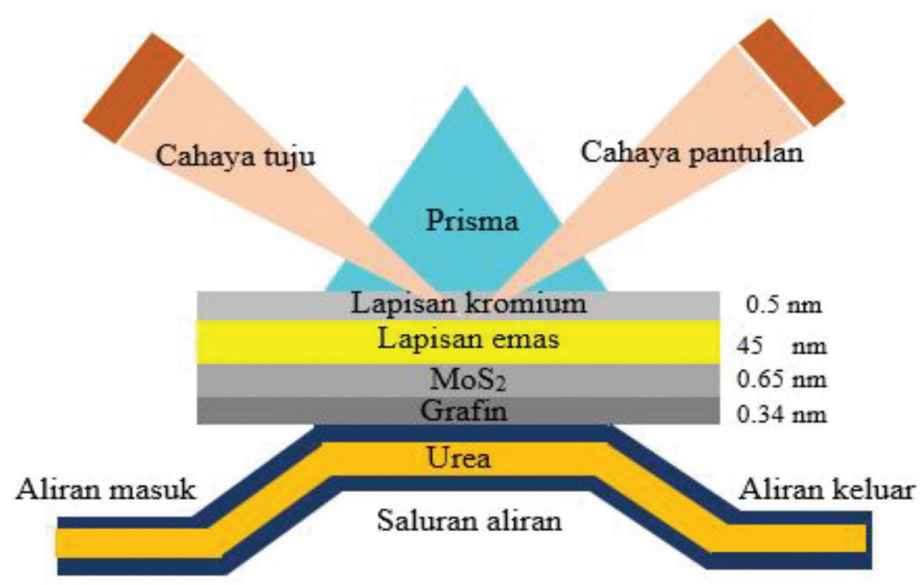

RAJAH 2. Gambarajah biosensor SPR berdasarkan tatasusunan Kretschmann 


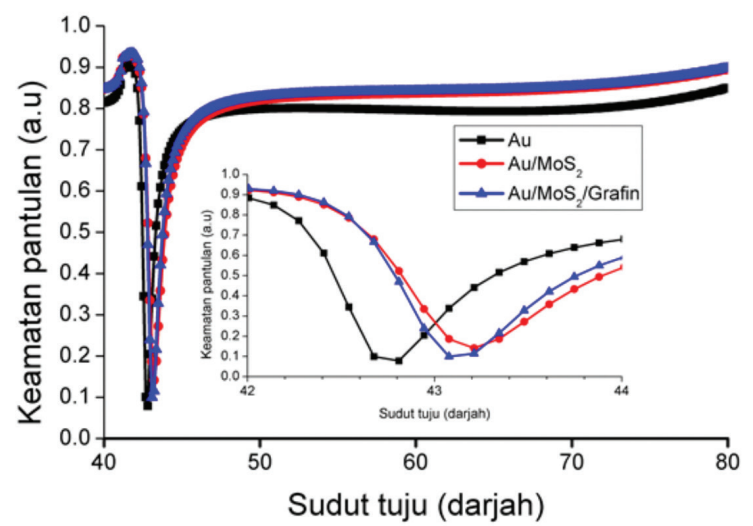

(a)

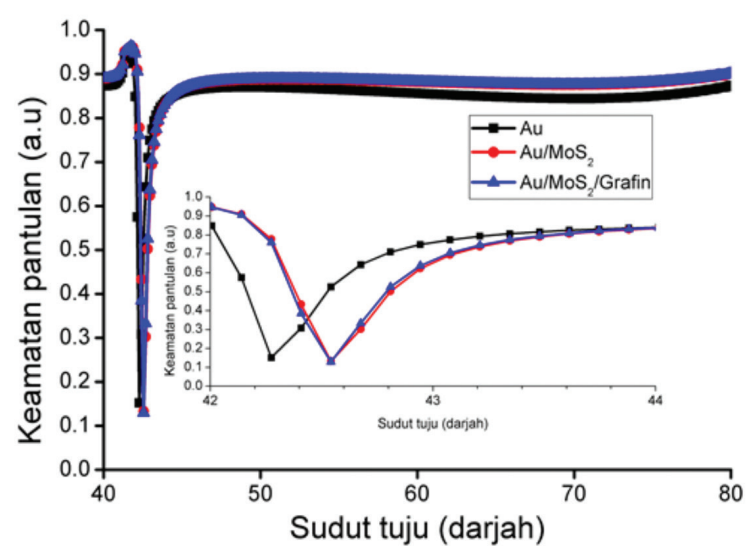

(b)

RAJAH 3. Lengkung simulasi SPR pada panjang gelombang a) $670 \mathrm{~nm}$ dan b) $785 \mathrm{~nm}$

Struktur I. Antara struktur yang dicadangkan, anjakan lengkung tersebut menunjukkan junaman yang terdalam pada sudut resonans berikutan perambatan gelombang pada lapisan grafin. Selain itu, boleh diperhatikan bahawa sudut resonans Struktur III pada 670 dan $785 \mathrm{~nm}$ masingmasing adalah $43.0769^{\circ}$ dan $42.5418^{\circ}$ serta lebih tinggi berbanding Struktur I $\left(42.8098^{\circ}\right.$ dan $\left.42.2742^{\circ}\right)$. Oleh yang demikian, ini menunjukkan bahawa sensor SPR dengan lapisan grafin mempunyai kehilangan yang minimum dan pemindahan tenaga yang maksimum berbanding dengan biosensor yang hanya terdiri daripada $\mathrm{Au}$ (Struktur I). Keputusan menunjukkan bahawa penurunan $\theta_{\text {res }}$ menurut tertib $\mathrm{Au} / \mathrm{MoS}_{2} /$ grafin $>\mathrm{Au} / \mathrm{MoS}_{2}>\mathrm{Au}$ untuk ketebalan yang sama. Oleh itu, ini membuktikan bahawa peningkatan $\theta_{\text {res }}$ berlaku disebabkan oleh peningkatan ketebalan lapisan sensor.

Rajah 4 menunjukkan nilai $R_{\min }$ dan FWHM untuk struktur dengan $\mathrm{Au}$ (Struktur I), $\mathrm{Au} / \mathrm{MoS}_{2}$ (Struktur II) dan $\mathrm{Au} / \mathrm{MoS}_{2} /$ grafin (Struktur III) pada 670 dan $785 \mathrm{~nm}$. Untuk prestasi biosensor yang lebih baik, nilai $R_{\text {min }}$ yang minimum berserta dengan kepekaan yang meningkat adalah dikehendaki. Struktur III menunjukan nilai $R_{\min }$ terendah iaitu 0.1 dan 0.1294 pada $670 \mathrm{~nm}$ dan $785 \mathrm{~nm}$. Oleh itu, adalah perlu dinyatakan bahawa biosensor yang

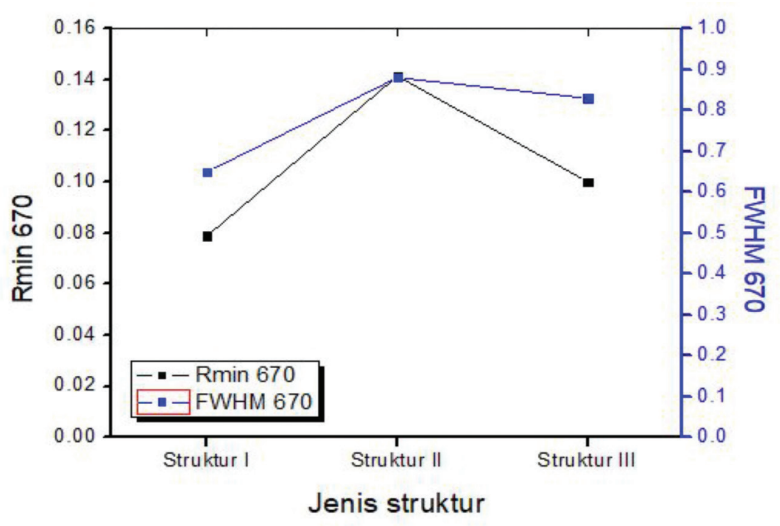

(a)

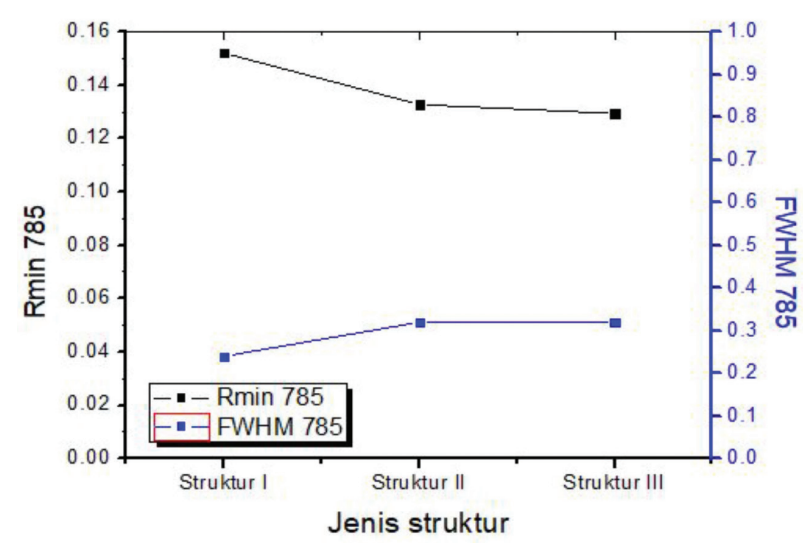

(b)

RAJAH 4. Keamatan minima $\left(R_{\text {min }}\right)$ dan FWHM untuk struktur sensor $\mathrm{Au}$ (Struktur I), Au/MoS $\left(\right.$ Struktur II) dan $\mathrm{Au} / \mathrm{MoS}_{2} /$ Grafin (Struktur III) untuk a) $670 \mathrm{~nm}$ b) $785 \mathrm{~nm}$

dicadangkan ini menunjukkan pengesanan yang lebih baik berbanding dua struktur sensor yang lain. Dapat diperhatikan bahawa lengkung pantulan pada panjang gelombang $785 \mathrm{~nm}$ jauh lebih sempit berbanding panjang gelombang $670 \mathrm{~nm}$. Nilai FWHM ini dikira sebagai $\theta_{\text {tinggi }}-\theta_{\text {rendah }}$ dengan sudut bawah dan atas masingmasing ditandakan sebagai $\theta_{\text {rendah }}$ dan $\theta_{\text {tinggi. }}$. Struktur III menunjukkan nilai FWHM lebih kecil pada panjang gelombang $785 \mathrm{~nm}$ berbanding $670 \mathrm{~nm}$ iaitu 0.32 dan 0.83 . Selain itu, dapat dilihat bahawa dengan penambahan ekalapisan $\mathrm{MoS}_{2}$ dan lapisan grafin pada lapisan logam emas, nilai $R_{\text {min }}$ dan FWHM telah meningkat. Penambahan lapisan $\mathrm{MoS}_{2}$ menghasilkan kehilangan tenaga elektron yang lebih tinggi dan mengurangkan ketepatannya. Ini adalah berikutan fenomena plasmon permukaan menjadi lembap lalu menghasilkan lengkung SPR yang lebih cetek dan lebih luas dengan penambahan lapisan sensor (Maurya \& Prajapati 2016).

Rajah 5 menunjukkan lengkung SPR untuk ketiga-tiga struktur sensor yang diplotkan mengikut indeks biasan medium penderiaan 1.335 dan 1.342 untuk panjang gelombang 670 dan $785 \mathrm{~nm}$. Ia jelas dilihat bahawa sudut resonans berganjak dengan perubahan indeks biasan medium penginderaan. 


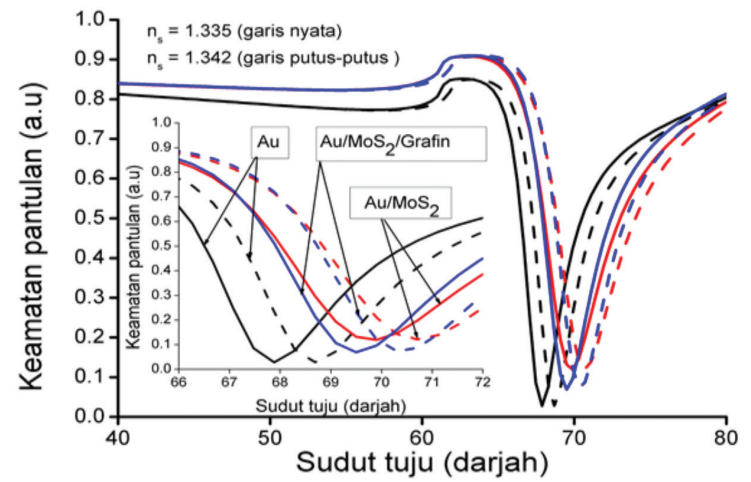

(a)

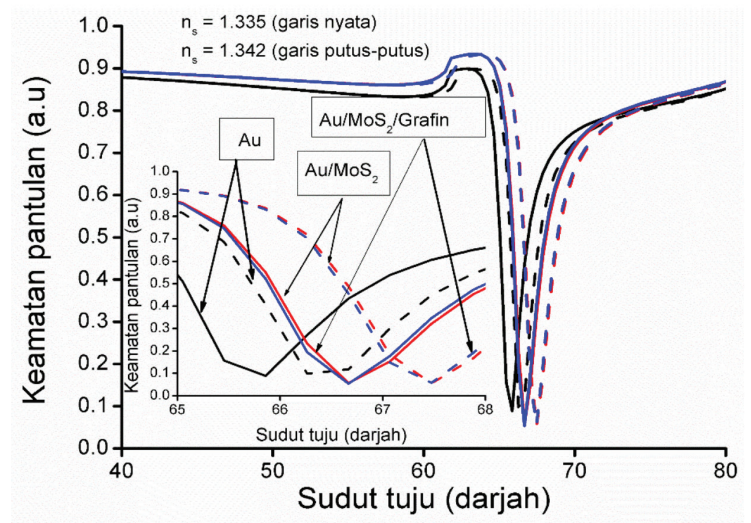

(b)

RAJAH 5. Lengkung pantulan pada semua struktur dengan indeks biasan 1.335 dan 1.342 pada panjang gelombang a) $670 \mathrm{~nm}$ b) $785 \mathrm{~nm}$

JADUAL 1. Kepekaan biosensor mengikut indeks biasan 1.335 dan 1.342 pada panjang gelombang 670 dan $785 \mathrm{~nm}$

\begin{tabular}{lcccccc}
\hline \multirow{2}{*}{ Jenis Struktur } & \multicolumn{3}{c}{$670 \mathrm{~nm}$} \\
\cline { 2 - 7 } & $\begin{array}{c}\theta_{\text {res }}\left({ }^{\circ}\right) \text { pada } \\
1.335\end{array}$ & $\begin{array}{c}\theta_{\text {res }}\left({ }^{\circ}\right) \text { pada } \\
1.342\end{array}$ & $\mathrm{~S}=\Delta \theta_{\text {res }} / \Delta \mathrm{n}_{\mathrm{s}}$ & $\begin{array}{c}\theta_{\text {res }}\left({ }^{\circ}\right) \text { pada } \\
1.335\end{array}$ & $\begin{array}{c}\theta_{\text {res }}\left({ }^{\circ}\right) \text { pada } \\
1.342\end{array}$ & $S=\Delta \theta_{\text {res }} / \Delta \mathrm{n}_{\mathrm{s}}$ \\
\hline $\mathrm{Au}($ Struktur I) & 67.88 & 68.69 & 115.71 & 65.86 & 66.26 & 57.14 \\
$\mathrm{Au} / \mathrm{MoS}_{2}$ (Struktur II) & 69.90 & 70.71 & 115.71 & 66.67 & 67.47 & 114.29 \\
$\mathrm{Au} / \mathrm{MoS}_{2} /$ Grafin (Struktur III) & 69.50 & 71.11 & 230.00 & 66.67 & 67.88 & 172.86 \\
\hline
\end{tabular}

Jadual 1 menunjukkan sudut resonans $\left(\theta_{\text {res }}\right)$ dan tahap kepekaan bagi kedua-dua panjang gelombang. Dalam jadual ini, dapat diperhatikan bahawa tahap kepekaan meningkat apabila nilai indeks biasan adalah tinggi dengan peratusan kepekaan meningkat sebanyak $98 \%$ dan 202\% pada struktur III berbanding struktur I masing-masing pada panjang gelombang 670 dan $785 \mathrm{~nm}$.

\section{KESIMPULAN}

Dalam analisis ini, biosensor dengan ekalapisan $\mathrm{MoS}_{2}$ dan lapisan grafin untuk pengesanan urea telah dicadangkan. Analisis berangka menunjukkan bahawa dengan penambahan ekalapisan $\mathrm{MoS}_{2}$ dan lapisan grafin, kadar peratus peningkatan kepekaan biosensor urea yang dicadangkan $\mathrm{Au} / \mathrm{MoS}_{2}$ /grafin berbanding struktur biosensor Au konvensional adalah $98 \%$ dan $202 \%$ boleh dicapai pada panjang gelombang 670 dan $785 \mathrm{~nm}$. Keadaan ini berlaku disebabkan oleh peningkatan penyerapan pada struktur sensor. Selain daripada itu, FWHM telah meningkat kerana fenomena lembapan permukaan plasmon. Oleh itu, dapat dinyatakan bahawa biosensor yang dicadangkan ini mempunyai potensi yang baik dalam pengesanan urea dengan menghasilkan ikatan biomolekul yang lebih baik pada permukaan logam.

\section{PENGHARGAAN}

Kajian ini telah disokong oleh Kementerian Pelajaran Malaysia dengan menggunakan Geran AKU-95 Pusat Kecemerlangan Institusi Tinggi (HiCOE) bersama geran daripada Universiti Kebangsaan Malaysia iaitu DIP-2016022 dan GUP-2016-062. Penulis ingin mengucapkan 
terima kasih kepada Institut Kejuruteraan Mikro dan Nanoelektronik (IMEN), Universiti Kebangsaan Malaysia dan MyBrain atas sokongan yang telah diberikan.

\section{RUJUKAN}

Ahmad, S.I. 2010. Studies on some biophysical aspects of human renal excretory fluid. Ph.D dissertation, Dept Phys, JNTU, Hyderabad, India (Tidak diterbitkan).

Aksimsek, S. \& Sun, Z. 2016. Graphene-MoS 2 heterostructure based surface plasmon resonance biosensor. IEEE Electromagnetic Theory 2(3): 12-13.

Chia, C.H., Razali, Nu. F., Sajab, M.S., Zakaria, S., Huang, N.M. \& Lim, H.N. 2013. Methylene blue adsorption on graphene oxide. Sains Malaysiana 42(6): 819-826.

Iqbal, N., Choudhury, P.K. \& Menon, P.S. 2015. Scattering from silver metal cylinder due to L-nihility coated with conducting sheath helix embedded dielectric medium. Electromagnetic Waves and Application 29(10): 1354-1374. doi:10.1080/09 205071.2015.1044128

Jamil, N.A., Menon, P.S., Said, F.A., Tarumaraja, K.A. \& Mei, G.S. 2017a. Graphene-based surface plasmon resonance urea biosensor using Kretschmann configuration. IEEE Regional Symposium on Micro and Nanoelectronics. pp. 112-115.

Jamil, N.A.B., Menon, P.S., Mei, G.S., Shaari, S. \& Majlis, B.Y. 2017b. Urea biosensor utilizing graphene-MoS2 and Kretschmann-based SPR. TENCON 2017 - 2017 IEEE Region 10 Conference. pp. 1973-1977. IEEE. doi:10.1109/ TENCON.2017.8228183

Jussila, H., Yang, H., Granqvist, N. \& Sun, Z. 2016. Surface plasmon resonance for characterization of large-area atomiclayer graphene film. Optica 3(2): 151-158. doi:10.1364/ OPTICA.3.000151.

Kravets, V.G., Jalil, R., Kim, Y.J., Ansell, D., Aznakayeva, D.E., Thackray, B., Britnell, L., Belle, B.D., Withers, F., Radko, I.P., Han, Z., Bozhevolnyi, S.I., Novoselov, K.S., Geim, A.K. \& Grigorenko, A.N. 2014. Graphene-protected copper and silver plasmonics. Scientific Reports 4: 5517. doi:10.1038/ srep05517.

Lee, H.K., Josephine Liew, Y.C., Zainal Abidin, T., Mohammad Shuhazlly, M., Janet Lim, H.N., Fakhrurrazi, A., Leong, Y.J., Chang,F.D. \& Burhanuddin Yeop, M. 2016. Synthesis of zinc selenide/graphene oxide composite via direct and indirect hydrothermal method. Sains Malaysiana 45(8): 1201-1206.

Maurya, J.B. \& Prajapati, Y.K. 2016. A comparative study of different metal and prism in the surface plasmon resonance biosensor having MoS2-graphene. Optical and Quantum Electronics 48(5): 1-12. doi:10.1007/s11082-016-0562-6

Maurya, J.B., Prajapati, Y.K., Singh, V. \& Saini, J.P. 2015. Sensitivity enhancement of surface plasmon resonance sensor based on graphene-MoS2 hybrid structure with TiO2-SiO2 composite layer. Applied Physics a-Materials Science \& Processing 121(2): 525-533. doi:10.1007/s00339-0159442-3.

Maurya, J.B., Prajapati, Y.K., Singh, V., Saini, J.P. \& Tripathi, R. 2016. Improved performance of the surface plasmon resonance biosensor based on graphene or MoS2 using silicon.

Mukhtar, W.M., Shaari, S., Ehsan, A.A. \& Menon, P.S. 2014. Electro-optics interaction imaging in active plasmonic devices. Optical Materials Express 4(3): 424. doi:10.1364/ OME.4.000424.

Optics Communications 359: 426-434. doi:10.1016/j. optcom.2015.10.010.
Mukhtar, W.M., Menon, P.S., Shaari, S., Malek, M.Z.A. \& Abdullah, A.M. 2013. Angle shifting in surface plasmon resonance: Experimental and theoretical verification. Journal of Physics: Conference Series 431: 12028. doi:10.1088/17426596/431/1/012028.

Ouyang, Q., Zeng, S., Jiang, L., Hong, L., Xu, G., Dinh, X.Q., Qian, J., He, S., Qu, J., Coquet, P. \& Yong, K-T. 2016. Sensitivity enhancement of transition metal dichalcogenides/ silicon nanostructure-based surface plasmon resonance biosensor. Scientific Reports 6(March): 28190. doi: 10.1038/ srep28190.

Rubio-Bollinger, G., Guerrero, R., de Lara, D.P., Quereda, J., Vaquero-Garzon, L., Agraït, N., Bratschitsch, R. \& Castellanos-Gomez, A. 2015. Enhanced visibility of MoS2, MoSe2, WSe2 and black-phosphorus: Making optical identification of 2D semiconductors easier. Electronics 4(4): 847-856. doi:10.3390/electronics4040847.

Said, F.A., Menon, P.S., Rajendran, V., Shaari, S. \& Majlis, B.Y. 2017. Investigation of graphene-on-metal substrates for SPR-based sensor using finite-difference time domain. IET Nanobiotechnology 11(8): 981-986. doi:10.1049/ietnbt.2017.0051.

Said, F.A., Menon, P.S., Nawi, M.N., Jalar, A. \& Majlis, B.Y. 2016. Copper-graphene SPR-based biosensor for urea detection. IEEE International Conference on Semiconductor Electronics, Proceedings. pp. 264-267.

Said, F.A., Menon, P.S., Kalaivani, T., Mohamed, M.A., Abedini, A., Shaari, S., Majlis, B.Y. \& Retnasamy, V. 2015a. FDTD analysis of structured metallic nanohole films for LSPRbased biosensor. IEEE Regional Symposium on Micro and Nanoelectronics (RSM). hlm. 1-4. IEEE. doi:10.1109/ RSM.2015.7355024.

Said, F.A., Menon, P.S., Shaari, S. \& Majlis, B.Y. 2015b. FDTD analysis on geometrical parameters of bimetallic localized surface plasmon resonance-based sensor. 6th International Conference on Intelligent Systems, Modelling and Simulation. hlm. 242-245. IEEE. doi:10.1109/ISMS.2015.12.

Said, F.A., Susthitha Menon, P., Shaari, S. \& Majlis, B.Y. 2015c. FDTD analysis on geometrical parameters of bimetallic localized surface plasmon resonance-based sensor and detection of alcohol in water. International Journal of Simulation: Systems, Science and Technology 16(4): 6.1-6.5. doi:10.5013/IJSSST.a.16.04.06.

Tarumaraja, K.A., Menon, P.S., Said, F.A., Jamil, N.A., Ehsan, A.A., Shaari, S., Majlis, B.Y. \& Jalar, A. 2016. FDTD numerical analysis of SPR sensing using graphene-based photonic crystal. IEEE International Conference on Semiconductor Electronics, Proceedings. hlm. 79-81.

Verma, R., Gupta, B.D. \& Jha, R. 2011. Sensitivity enhancement of a surface plasmon resonance based biomolecules sensor using graphene and silicon layers. Sensors and Actuators, $B$ : Chemical 160(1): 623-631. doi:10.1016/j.snb.2011.08.039.

Institut Kejuruteraan Mikro dan Nanoelektronik (IMEN)

Universiti Kebangsaan Malaysia

43600 UKM Bangi, Selangor Darul Ehsan

Malaysia

*Pengarang untuk surat-menyurat; email: susi@ukm.edu.my

Diserahkan: 4 Oktober 2017

Diterima: 29 November 2017 